\title{
Comparative study on the fish diversity from natural and bauxite post- mining in wetland system of Bintan Island, Indonesia
}

\author{
TRI APRIADI ${ }^{1}$, GINANJAR PRATAMA ${ }^{2}$, RISANDI DWIRAMA PUTRA ${ }^{3}$, JUMSURIZAL $^{2}$, YALES VEVA JAYA ${ }^{3}$, \\ MUHAMMAD FIRDAUS ${ }^{1}$, HERU DIWAN ARPAS ${ }^{3}$, ANI SURYANTI ${ }^{4, \vartheta}$ \\ ${ }^{1}$ Aquatic Resources Management, Marine Science and Fisheries Faculty, Raja Ali Haji Maritime University, Tanjungpinang 29111, Indonesia. \\ ${ }^{2}$ Aquatic Product Technology, Marine Science and Fisheries Faculty, Raja Ali Haji Maritime University, Tanjungpinang 29111, Indonesia. \\ ${ }^{3}$ Marine Science, Marine Science and Fisheries Faculty, Raja Ali Haji Maritime University, Tanjungpinang 29111, Indonesia. \\ ${ }^{4}$ Fisheries Social Economic, Marine Science and Fisheries Faculty, Raja Ali Haji Maritime University, Tanjungpinang 29111, Indonesia. ^email: \\ yanti.ajb@gmail.com
}

Manuscript received: 14 March 2018. Revision accepted: 1 May 2018

\begin{abstract}
Apriadi T, Pratama G, Putra RD, Jumsurizal, Jaya YV, Firdaus M, Arpas HD, Suryanti A. 2018. Comparative study on the fish diversity from natural and bauxite post-mining in wetland system of Bintan Island, Indonesia. Biodiversitas 19: 967-973. In this study, the fish populations between two different wetland systems in Bintan Island, Indonesia, i.e., bauxite post-mining (Kijang) and natural wetland (Toapaya) were compared and to propose a newly index namely Environomic of Fishes Index (EFI) to their respective ecosystems. The purposive random sampling at six stations, each of three stations representing bauxite mining (Kijang) and three stations representing a natural wetland (Toapaya) were used in this research. The numbers of fish species and the abundance were enumerated. The new index derived from the value of diversity index (Shannon), similarity index (Evenness), dominance index (Simpson's), conservation status, and economic value were also evaluated. The natural wetland has higher fish diversity than bauxite post-mining. The total species found were twenty-four. The same seven species were found in both areas. Twelve species were obtained from bauxite post-mining, and nineteen species were obtained from natural wetland. Puntius tetrazona and Rasbora heteromorpha were the common species in area study. The diversity and dominance index was at low category, Evenness index was at high category in all stations, except in tidal swamp station at bauxite post-mining. The EFI in natural wetland was higher than bauxite post-mining. The three community index value, economic value, and conservation status of natural wetland were higher than bauxite post-mining.
\end{abstract}

Keywords: Conservation status, fish diversity, Shannon, Evenness, Simpson's

\section{INTRODUCTION}

Inland waters and freshwater biodiversity constitute a valuable natural resource, in economic, cultural, aesthetic, scientific and educational terms (Dudgeon et al. 2006). The economic foundation of a decision for or against the protection of biodiversity requires the consideration of all costs and benefits related to it. It is well known that the main problem of including the range of biodiversity services in economic choices is, that many of these services are not valued on markets (Fromm 2000). Under CITES guidelines, once an endangered species can be bred in captivity, applications can be made for its trade to be allowed on a controlled basis, but many freshwater fish species have been over wild-exploited for the ornamental fish trade ( $\mathrm{Ng}$ and Tan 1997) and consumption. Over 10000 fish species live in freshwater (Lundberg et al. 2000 ), approximately $40 \%$ of global fish diversity and onequarter of global vertebrate diversity. The five major threat categories (over-exploitation, water pollution, flow modification, habitat degradation, species invasions) and their established or potential interactive impacts on freshwater biodiversity (Dudgeon et al. 2006).

Bauxite mining is one of the five major threat categories. It was decreased over time, but the environmental damage that occurs is not fully improved
(Parrotta and Knowles 1999). It affects the survival of flora and fauna found in fresh water for the entire territory of post-mining. Because vegetation responds differentially to the level of nutrients available to them and the degree of anaerobiosis present in the soil, flooding or soil saturation, it has been recognized as being the primary factor controlling freshwater wetland plant distribution patterns (Conner et al. 1981; Parsons and Ware 1982).

Bintan Island was reputed for bauxite mining field under the concession of national company its monopole, called PT Aneka Tambang Tbk until 2000. After their closure, the open land former bauxite mine approximately 1000 ha were revegetated but illegal mining was then occupied and results in the land degradation.

The wetlands in Bintanwere also influenced by tides and rainfall due to the distance between river and swamp to the coast not far away. The allocation of fish in Bintan follow the distribution pattern adapted to it. Recently, many species endemic and unique of freshwater fish in Bintan, discovered by researchers, e.g., $\mathrm{Ng}$ and Lim (1993), Kottelat and Lim (1994), Tan and Tan (1994), Ng and Kottelat (1994), Ng and Lim (1995), Ng and Tan (1997), Kottelat and Ng (1998), and Kottelat et al. (2006).

A comparative study of these areas both in terms of freshwater fish species composition, structure community, and study of environomic fish were required. The main 
objective this study was to record and compare the fish populations between two different wetland systems (around the reservoir, creek, and swamp), by comparing aspects of area bauxite post-mining (Kijang) and natural (Toapaya) and study environomic of fishes, respectively.

\section{MATERIALS AND METHODS}

\section{Study area}

The fishes were collected in January 2017 (dry season) in bauxite post-mining wetland (Kijang, K) and naturally wetland (Topaya), in Bintan Island, Riau Islands Province of Indonesia. Sampling has been done five times at each station. Each location consisted of three stations: (i) around reservoir, (ii) creek, and (iii) swamp (tidal swamp in Kijang and peat swamp in Toapaya) (Figure 1 and Table 1).

\section{Sampling methods}

The fishes were collected by hand scoop net $(30 \mathrm{~cm}$ length, $25 \mathrm{~cm}$ wide, and $3 \mathrm{~mm}$ mesh size). Physicochemical water parameters $(\mathrm{pH}, \mathrm{DO}$, temperature, and salinity) were checked by Multitester Lutron YK 2005 WA and hand refractometer (APHA 2012).

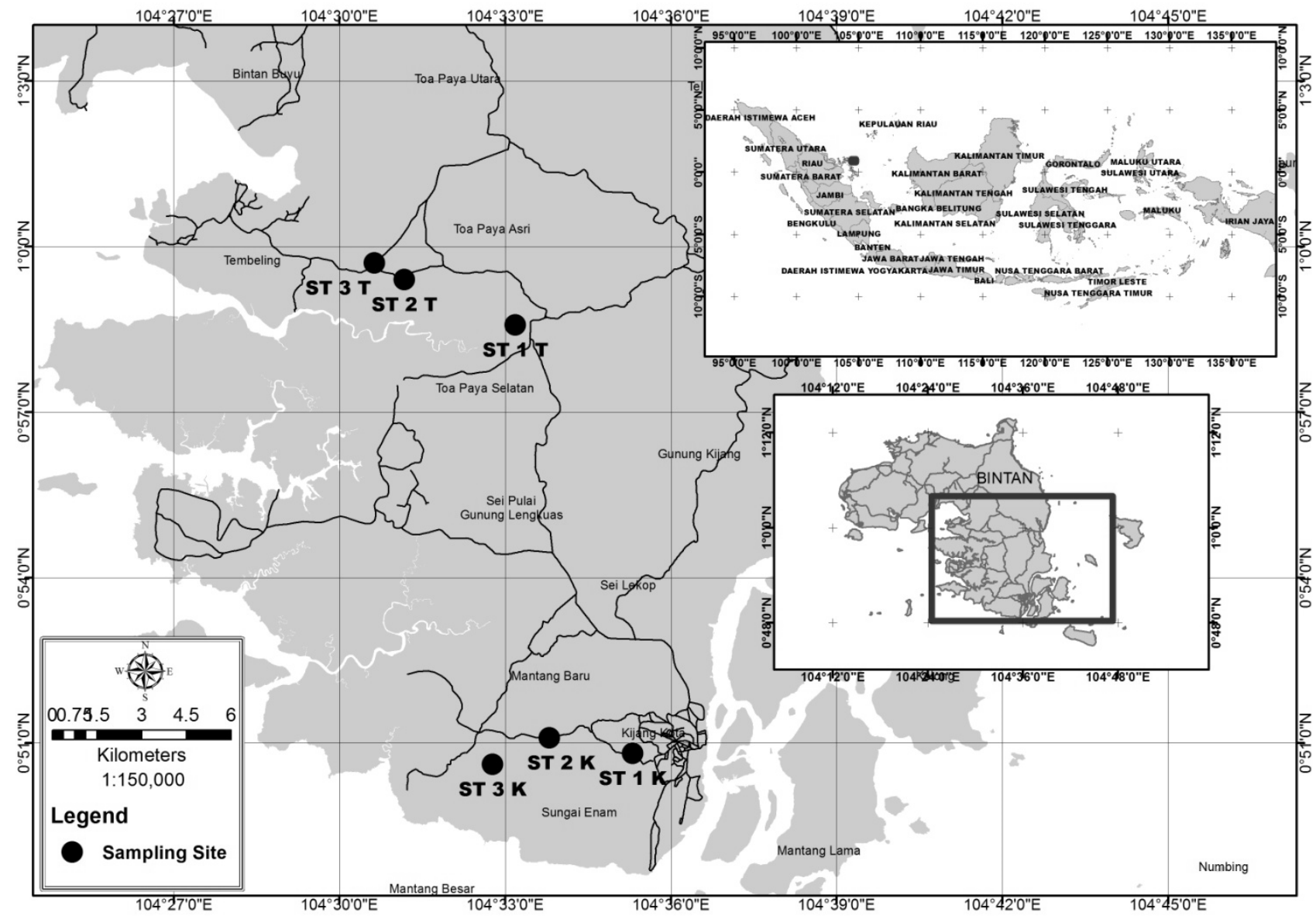

Figure 1. Sampling locations in two spatially isolated in Bintan Island, Riau Islands Province, Indonesia. ST $1=$ around the reservoir, ST 2 = creek, ST 3 = swamp

Table 1. Sampling coordinate of study site in Bintan Island, Riau Islands Province, Indonesia

\begin{tabular}{ccccccc}
\hline \multirow{2}{*}{$\begin{array}{c}\text { Sampling } \\
\text { site }\end{array}$} & $\begin{array}{c}\text { Kround the } \\
\text { reservoir (ST 1) }\end{array}$ & Creek (ST 2) & $\begin{array}{c}\text { Tidal swamp } \\
\text { (ST 3) }\end{array}$ & $\begin{array}{c}\text { Around the } \\
\text { reservoir (ST 1) }\end{array}$ & $\begin{array}{c}\text { Toapaya } \\
\text { Creek (ST 2) }\end{array}$ & $\begin{array}{c}\text { Peat swamp } \\
\text { (ST 3) }\end{array}$ \\
\hline Coordinate & $00.84513^{\circ} \mathrm{N}$ & $00.85218^{\circ} \mathrm{N}$ & $00.84739^{\circ} \mathrm{N}$ & $00.97695^{\circ} \mathrm{N}$ & $00.99386^{\circ} \mathrm{N}$ & $01.00416^{\circ} \mathrm{N}$ \\
& $104.59158^{\circ} \mathrm{E}$ & $104.56399^{\circ} \mathrm{E}$ & $104.55233^{\circ} \mathrm{E}$ & $104.56168^{\circ} \mathrm{E}$ & $104.52690^{\circ} \mathrm{E}$ & $104.51522^{\circ} \mathrm{E}$ \\
Elevation & 26 & 12 & 7 & 8 & 13 & -4 \\
\hline
\end{tabular}




\section{Data analysis}

All fishes caught were identified using standard taxonomic keys following Kotellat et al. (1993) and Tan and Tan (1994). The numbers of fish species and the number of individuals in each species were enumerated. Three community indexes were used to determine fish community structure, i.e. species diversity Shannon-Wiener $\left(\mathrm{H}^{\prime}\right)$, species Evenness (E), and species dominance (C) (Krebs 1999).

$\mathrm{H}^{\prime}$ is determined by using the formula:

$$
\mathrm{H}^{\prime}=\sum_{\mathrm{i}=1}^{\mathrm{s}}-\left(\mathrm{P}_{\mathrm{i}} \ln \mathrm{P}_{\mathrm{i}}\right)
$$

Where: $\mathrm{H}^{\prime}=$ index diversity Shannon-Wiener, $\mathrm{Pi}=$ fraction of the entire population made up of species i, S = numbers of species encountered, $\sum=$ sum from species 1 to species $\mathrm{S}, \mathrm{E}$ is determined by using the formula:

$$
\mathrm{E}=\frac{\mathrm{H}^{\prime}}{\mathrm{H} \max }
$$

Where: $\mathrm{E}=$ species Evenness, $\mathrm{H}^{\prime}=$ Index diversity Shannon-Wiener, H max = Index diversity maximum (ln $\mathrm{S}), \mathrm{S}=$ number of species, and $\mathrm{C}$ is determined by using the formula:

$$
\mathrm{C}=\Sigma\left[\frac{\mathrm{ni}}{\mathrm{N}}\right]^{2}
$$

Where: $\mathrm{C}=$ Index dominance Simpson, $\mathrm{ni}=$ number of individuals of each species, $\mathrm{N}=$ number of individuals of all species.

\section{Enviromic Fish Index (EFI)}

This indexing is used to determine the impact of the presence of fish in the wetland systems for human being. The parameters used in this indexing were the value of diversity index (Shannon), similarity index (Evenness), dominance index (Simpson's), conservation status, and economic value. EFI calculation was done by giving a proportionally score for all categories in each indexing (Table 2).

The total score on each indexing would be multiplied by the percentage proportion: Shannon-Wiener index (20\%), Evenness index (20\%), Simpson's index (20\%), Economic Value (20\%), and Conservation Status (20\%), by the equation below. Based on the equation, the EFI

\begin{tabular}{|c|c|c|}
\hline Index & Category & Score \\
\hline \multirow[t]{5}{*}{ Shannon-Wiener Index } & $>6.61$ & 5 \\
\hline & $4.21-6.60$ & 4 \\
\hline & $2.81-4.20$ & 3 \\
\hline & $1.41-2.80$ & 2 \\
\hline & $0.00-1.40$ & 1 \\
\hline \multirow[t]{5}{*}{ Evenness Index } & $0.81-1.00$ & 5 \\
\hline & $0.61-0.80$ & 4 \\
\hline & $0.41-0.60$ & 3 \\
\hline & $0.21-0.40$ & 2 \\
\hline & $0.00-0.20$ & 1 \\
\hline \multirow[t]{5}{*}{ Dominance Index } & $0.81-1.00$ & 1 \\
\hline & $0.61-0.80$ & 2 \\
\hline & $0.41-0.60$ & 3 \\
\hline & $0.21-0.40$ & 4 \\
\hline & $0.00-0.20$ & 5 \\
\hline \multirow[t]{5}{*}{ Economic Value Index } & Very expensive & 5 \\
\hline & Expensive & 4 \\
\hline & Moderate & 3 \\
\hline & Common & 2 \\
\hline & Non-economic & 1 \\
\hline \multirow{9}{*}{$\begin{array}{l}\text { Conservation Status } \\
\text { Index }\end{array}$} & Extinct $(\mathrm{EX})$ & \\
\hline & Extinct in the Wild (EW) & 5 \\
\hline & Critically Endangered (CR) & \\
\hline & Endangered $(\mathrm{EN})$ & 4 \\
\hline & Vulnerable (VU) & \\
\hline & Near Threatened (NT) & 3 \\
\hline & Least Concern (LC) & 3 \\
\hline & Data Deficient (DD) & 2 \\
\hline & Not Evaluated (NE) & 1 \\
\hline
\end{tabular}
categories consisted of five categories (Table 3)
Table 2. Scoring for all categories in each index

Table 3. EFI category

\begin{tabular}{ll}
\hline Total score & $\mathbf{Y}$ \\
\hline $4.01-5.00$ & Very high \\
$3.01-4.00$ & High \\
$2.01-3.00$ & Moderate \\
$1.01-2.00$ & Low \\
$0.00-1.00$ & Very low \\
\hline
\end{tabular}
$\mathrm{EFI}=\left(\sum_{i=1}^{n}\right.$ Shanon $\left.* 20 \%\right)+\left(\sum_{i=1}^{n}\right.$ Eveness $\left.* 20 \%\right)+\left(\sum_{i=1}^{n}\right.$ SImpson $\left.* 20 \%\right)+\left(\sum_{i=1}^{n}\right.$ Economic value $\left.* 20 \%\right)+\left(\sum_{i=1}^{n}\right.$ Conservation status $\left.* 20 \%\right)$ 


\section{RESULTS AND DISCUSSION}

The total species found were twenty-four. The same seven species were found in both areas (Table 4). Twelve species were obtained from Kijang areas whereas nineteen species were obtained from Toapaya areas (Table 5). In both areas, most species were found in around the reservoir, the number of individuals was caught more than half of total number of fishes.

Puntius tetrazona has the highest abundance proportion in Kijang (34\%), and Sundasalanx microps was the lowest $(0.5 \%)$. In Toapaya, $R$. heteromorpha has the highest proportion $(23 \%)$, and the lowest abundance proportion were Ompok leiacanthus and Trichogaster trichopterus (0.2\%) (Figure 2).

Table 4. Fish diversity in Kijang and Toapaya in Bintan Island, Riau Islands Province, Indonesia

\begin{tabular}{|c|c|c|c|c|c|c|c|c|}
\hline \multirow[b]{2}{*}{ Species } & \multirow[b]{2}{*}{ Family } & \multicolumn{3}{|c|}{ Kijang } & \multicolumn{3}{|c|}{ Toapaya } & \multirow[b]{2}{*}{$\begin{array}{l}\text { Number of } \\
\text { individuals }\end{array}$} \\
\hline & & $\begin{array}{l}\text { Around } \\
\text { reservoir }\end{array}$ & Creek & $\begin{array}{c}\text { Tidal } \\
\text { Swamp }\end{array}$ & $\begin{array}{c}\text { Around } \\
\text { reservoir }\end{array}$ & Creek & $\begin{array}{c}\text { Peat } \\
\text { Swamp }\end{array}$ & \\
\hline Aplocheilus panchax & Aplochelidae & 17 & 20 & 5 & & & & 42 \\
\hline Betta edithae & Osphronemidae & & 2 & & & & & 2 \\
\hline B. pugnax & Osphronemidae & & & & 2 & 5 & 1 & 8 \\
\hline Boraras maculata & Cyprinidae & & 10 & & & & & 10 \\
\hline Brachygobius doriae & Gobiidae & & & & 2 & & & 2 \\
\hline Hampala macrolepidota & Cyprinidae & & & & 15 & & 10 & 25 \\
\hline Hemirhamphodon pogonognathus & Hemirhamphidae & & 5 & & & 15 & & 20 \\
\hline Luciocephalus pulcher & Osphronemidae & & & & & 3 & 2 & 5 \\
\hline Macrognathus maculatus & Mastacembelidae & & & & & 2 & & 2 \\
\hline Nandus nebulosus & Nandidae & & & & & 2 & 1 & 3 \\
\hline Nemacheilus selangoricus & Balitoridae & & & & 30 & & & 30 \\
\hline Ompok leiacanthus & Siluridae & & & & & 1 & & 1 \\
\hline Oryzias javanicus & Adrianichthyidae & 20 & & & & & & 20 \\
\hline P. hexazona & Cyprinidae & & & & & & 20 & 20 \\
\hline P. tetrazona & Cyprinidae & 15 & 2 & 50 & 60 & & 20 & 147 \\
\hline Rasbora argyrotaenia & Cyprinidae & 10 & 5 & & 20 & 10 & & 45 \\
\hline$R$. einthovenii & Cyprinidae & & 11 & & 30 & & & 41 \\
\hline R. gracilis & Cyprinidae & & 5 & & 15 & 4 & 35 & 59 \\
\hline R. heteromorpha & Cyprinidae & 10 & 5 & & 50 & 12 & 34 & 111 \\
\hline Sundasalanx microps & Sundasalangidae & 1 & & & & & & 1 \\
\hline Trichogaster trichopterus & Osphronemidae & 3 & 1 & & & & 1 & 5 \\
\hline Trichopsis vittata & Osphronemidae & & & & 3 & & & 3 \\
\hline
\end{tabular}

Table 5. The comparative species of Kijang and Toapaya in Bintan Island, Riau Islands Province, Indonesia

\begin{tabular}{|c|c|c|}
\hline Parameter & Kijang & Toapaya \\
\hline Species count & 12 & 19 \\
\hline Family count & 7 & 10 \\
\hline Catch $(\mathrm{n})$ & 197 & 422 \\
\hline Common species & P. tetrazona & R. heteromorpha \\
\hline Common family (n) & Cyprinidae (6) & Cyprinidae (8) \\
\hline Rare species & S. microps & O. leiacanthus \\
\hline Common species in peat swamp & P. tetrazona & R. gracilis \\
\hline Common species in creek & A. panchax & H. pogonognathus \\
\hline Common species in around the reservoir & O.javanicus & P. tetrazona \\
\hline Rare species in tidal swamp & A. panchax & N. nebulosus \\
\hline Rare species in creek & T. trichopterus & O. leiacanthus \\
\hline Rare species in around the reservoir & S. microps & C. striata \\
\hline
\end{tabular}

Note: $\mathrm{n}=$ amount

Table 6. Comparative ecological index

\begin{tabular}{lrrrrrr}
\hline \multirow{2}{*}{$\begin{array}{l}\text { Ecological } \\
\text { index }\end{array}$} & \multicolumn{2}{c}{ Kijang } & \multicolumn{3}{c}{ Toapaya } \\
\cline { 2 - 7 } H' & \multicolumn{1}{c}{ Around the reservoir } & \multicolumn{1}{c}{ Creek } & \multicolumn{1}{c}{ Tidal Swamp } & Around the reservoir & Creek & Peat Swamp \\
E & 1.72 & 2.00 & 0.30 & 2.06 & 1.95 & 0.83 \\
C & 0.89 & 0.87 & 0.44 & 0.83 & 0.85 \\
\end{tabular}




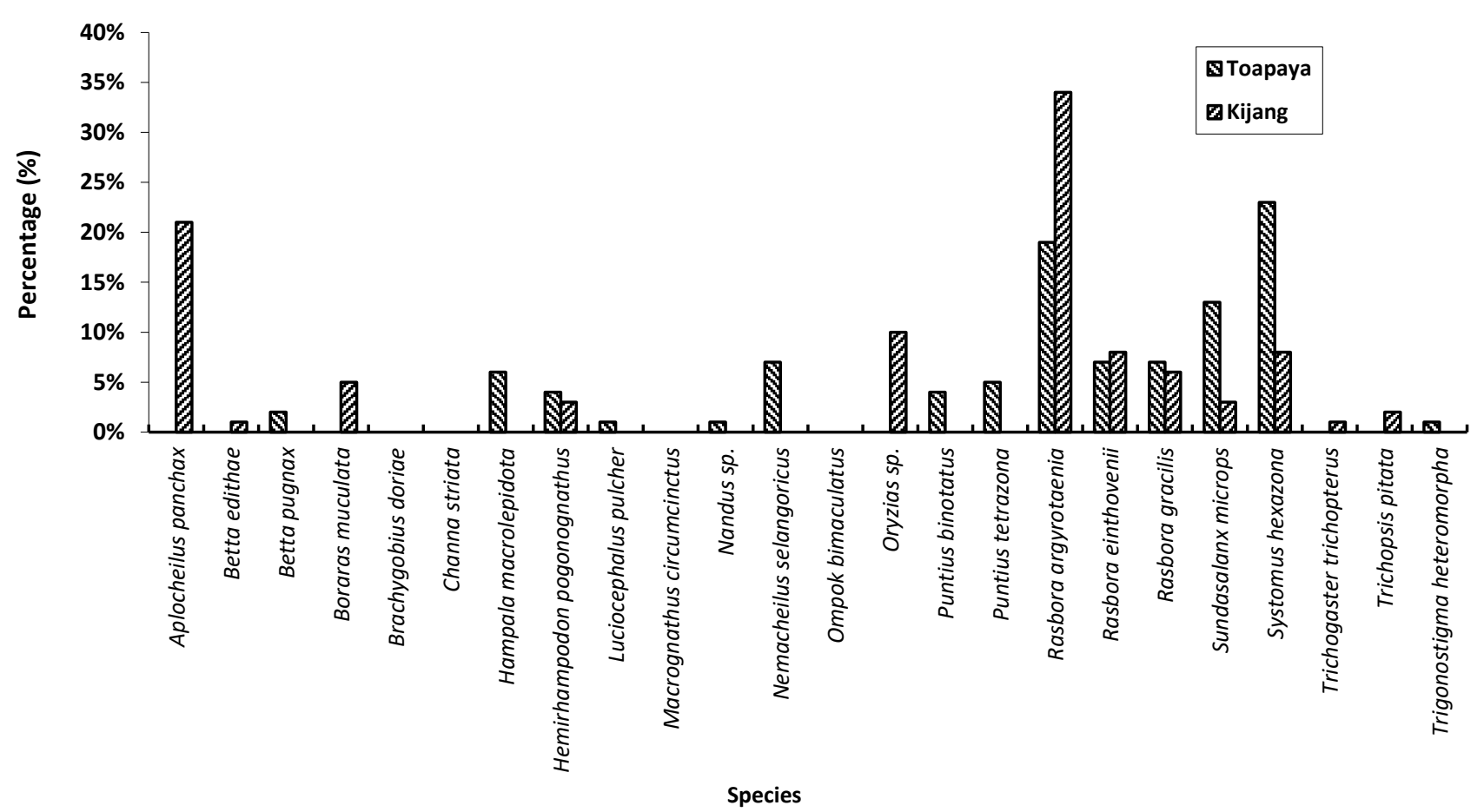

Figure 2. Fish species and percentage (\%) recorded at Kijang and Toapaya, Bintan Island, Riau Islands Province, Indonesia

Fish diversity in Bintan was influenced by environmental condition. Spatial distribution of species richness related to habitat differences and presence of microhabitats, substrate composition and water depth (Gordon et al. 2004). The value of $\mathrm{pH}$ and dissolved oxygen are parameters of water quality as an indicator of aquatic ecosystem health (Goudey 2003). Most aquatic biotas are sensitive to changes in $\mathrm{pH}$. Differences in water quality parameters between Toapaya and Kijang have determined the diversity of the location (Table 7). Besides, the types of soil in Bintan were organosol, humic clay, podzolic, podzolic yellow, and lithosol (Riau Islands Planning Agency 2003). The physicochemical value of land former bauxite mine is low when compared to natural forests or plantation. Soil texture bauxite post-mining was sandy clay with a ratio of clay, sand, and dust by $50 \%$, $40 \%$, and $10 \%$, respectively. Availability of nutrients $\mathrm{Ca}$, $\mathrm{Mg}, \mathrm{Na}$ and $\mathrm{K}$ bauxite post-mining were $0.72 ; 0.31 ; 0.45$ and $0.20 \mathrm{me} / 100 \mathrm{~g}$ (Sembiring 2008). The morphological areas of both Kijang and Toapaya were different. Soil texture in Kijang was dominated by sand, clay, and gravel that has bauxite deposits in large numbers (Sembiring 2008). On the other hand, Toapaya was dominated by soil, clay, and peat with smaller amounts of bauxite.

The diversity index was at low category in all stations, both of Kijang and Toapaya. Evenness index was at high category, except in Kijang tidal swamp (Table 6). Kijang tidal swamp has high dominance by $P$. tetrazona. High dominance in Kijang tidal swamp was indicated ecological stress by environment parameters (Table 7).

Both of them have lowland and hills, rivers, creeks, reservoir, and swamps (Riau Islands Planning Agency 2003). However, Kijang is a tidal swamp and which are in
Toapaya is a peat swamp (Table 7). Tidal swamps are rarely, if ever, subjected to dry conditions, and major rainstorms seem to have relatively little effect on river levels or upon water levels within swamps. The tide cycle (including seasonal and monthly changes in mean tide heights) seems to be the primary mechanism driving the hydrologic regime in tidal swamps (Reinhardt and Heshner 1992). The peat swamp forests affected by interdependence of the vegetation with the peat substrate, which relies on the maintenance of adequate water, canopy cover and leaf litter inputs (Yule 2010). Even though both sites are situated in Bintan, their topographical and hydrological characteristics are very different (Prentice and Parish 1992).

In advance of recorded freshwater fish in Bintan Island, which was conducted by Tan and Tan (1994). They have collected 59 species, but there several species not found, consisted by Brachygobius doriae, Hampala macrolepidota, Oryzias javanicus, P. tetrazona, Rasbora argyrotaenia, S. microps, and Trichopsis vittata. Species differences were found because of the different sites. Tan and Tan (1994) conducted a study in the middle to the north, while in this study conducted in the central to southern Bintan.

Genera of Betta and Rasbora were common species in Bintan Island. The others of species found in Bintan island were Betta miniopinna (Tan and Tan 1994), B. spilotogena ( $\mathrm{Ng}$ and Kottelat 1994), Encheloclarias kelioides ( $\mathrm{Ng}$ and Lim 1993), Parosphromenus bintan (Kottelat and $\mathrm{Ng}$ 1998), Parakysis longirostris, P. verrucosa ( Ng and Lim 1995), R. heteromorpha (Ng and Tan 1997), Paedocypris progenetica (Kottelat et al. 2006) and Bihunichthys monopteroides (Kottelat and Lim 1994). Wargasasmita 
(2002) indicated that species of $B$. miniopinna, $B$. spilotogena, and E. kelioides had been threatened species, based on IUCN status (2001).

Generally, the natural wetland has higher fish diversity than bauxite post-mining, although there were not significantly different. Bauxite post-mining could become ecological stress for the natural freshwater. The ecological stress, for example, water dynamics, affected by the species adaptation and dominance (Krebs 1999). Characteristic of Kijang tidal swamp in bauxite post-mining area that has a large water dynamics which allegedly led to the dominance and rare of $P$. tetrazona and Aplocheilus panchax. This indicated that $P$. tetrazona and $A$. panchax have a high tolerance to the salinity changes. In the natural condition, $P$. tetrazona could grow up to $6 \mathrm{ppt}$ (Abolhasani et al. 2014) and $A$. panchax in brackish water at low altitudes (Chandra et al. 2008). This ecological stress suspected cause of fish diversity decrease and loss native species. Wargasasmita (2002) reported that 17.3\% endemic fish species in Riau Islands were threatened by anthropogenic.

In Kijang, S. microps was recorded, it was the unique species, transparent teleosts and can be found in Kapuas River, Kalimantan Barat, Indonesia, and another from Khlong Falamee, Isthmus of Kra, southern Thailand (Roberts 1981), even though in Kijang was areas former mining. The most popular fish on the market has a $P$. tetrazona (tiger barb) and $R$. heteromorpha (harlequin rasbora). In this study, they are common species (Table 5) in both locations, respectively. $R$. heteromorpha has been popular in the trade for many decades and it ideal for community tanks. It was found as well known "ikan segitiga". Recently, reported by Ng and Tan (1997), during a major harvest, more than 100,000 pieces can be obtained within a week.

The environomic study has divided into indirect and direct value. Ecological (diversity index, similarity index, and dominance index) and conservation status (IUCN red list) included indirect value, and economic value included direct value. These were different from Edwards and Abviadi (1998), they were discovered by incorporate the concept of the value of biodiversity (and of other natural resources such as soil) into our accounting systems. Indeed, when the full value of a natural ecosystem is quantified, the results can be quite surprising, especially in the case of wetlands (Costanza et al. 1989).

According to $\mathrm{Ng}$ and Tan (1997), in the fish categories of economic value can be divided into three categories, which are bread-and-butter species (category I), wild- caught species (category II), and very expensive species (categories III). However, in this study, through the direct value (price approach) was divided into five categories. There were very expensive category (more than IDR 100000), expensive category (IDR 51000 to 100000), moderate (IDR 11000 to 50000), common (less than IDR 10000) and non-economic value (not evaluated value). The predatory species usually belong to the categories moderate, expensive, and very expensive, e.g., Channa striata, Luciocephalus pulcher, Nandus nebulosus, and genera of Betta. The common species were schooling fish and the other small fish such as Nemacheilus selangoricus, Puntius hexazona, P. tetrazona, genera of Rasbora, and many more. Furthermore, the non-economic species, consisted of Hemirhamphodon pogonognathus, $O$. javanicus, S. microps, and other species not evaluated value. The present observations and suggestions are based on many years of working closely with fish catchers, dealers and exporters in the region, not only on a scientific but also at the fisheries level ( $\mathrm{Ng}$ and Tan 1997).

Physico-chemical water parameters were meet to the water quality standard for fish growth (Table 7). Toapaya peat swamps had the lowest $\mathrm{pH}$ value; this corresponded to the characteristics of acidic peat swamps. All stations were freshwater, except tidal swamp in Kijang.

In Kijang was moderate environomic of fishes, whereas Toapaya was high environomic of fishes. Environomic fish index in Toapaya was higher than Kijang (Table 8). The three community index value, economic value, and conservation status of Toapaya were higher than Kijang.

The environomic study of fishes on Toapaya was higher than Kijang (Table 8), because of residual deposits mined were typically formed above this water (Grubb 1963), affect the existence of the surrounding ecosystem (Parrotta and Knowles 1999). Therefore, habitat degradation is brought about by an array of interacting factors and have resulted in population declines and range reduction of freshwater biodiversity (Dudgeon et al. 2006). It also causes the decline livelihood indirectly, so that has implications for human. In bauxite post-mining areas was included moderate environomic of fishes, whereas the natural wetland was included high environomic of fishes (Table 8). Bauxite residue can be helped neutralization acids sulfate soil and remove trace metals from solution (Lin et al. 2002). The difference not due to bauxite deposits (Menzies et al. 2004), but because of environmental damage caused by deforestation in bauxite mined lands ((Parrotta and Knowles 1999).

Table 7. Water quality in Kijang and Toapaya, Bintan Island, Riau Islands Province, Indonesia

\begin{tabular}{lcccccc}
\hline Water quality & \multicolumn{2}{c}{ Kijang } & \multicolumn{3}{c}{ Toapaya } \\
\cline { 2 - 6 } & Around the reservoir & Creek & Tidal swamp & Around the reservoir & Creek & Peat swamp \\
\hline & & & & & & \\
$\mathrm{pH}$ & 5.57 & 5.46 & 6.13 & 6.88 & 6.67 & 4.48 \\
Temperature $\left({ }^{\circ} \mathrm{C}\right)$ & 32.7 & 29.4 & 33.1 & 28.6 & 27.5 & 28.8 \\
Salinity $(\%$ ) & 0 & 0 & 2 & 0 & 0 & 5.4 \\
Dissolved Oxygen $(\mathrm{mg} / \mathrm{L})$ & 5.8 & 5.2 & 4.8 & 5.5 & 5.3 \\
\hline
\end{tabular}


Table 8. Environomic fish index

\begin{tabular}{lcc}
\hline Environomic Fish Index & Kijang & Toapaya \\
\hline Shannon-Wiener Index (20\%) & 0.33 & 0.40 \\
Eveness Index (20\%) & 0.87 & 0.93 \\
Simpson's Index (20\%) & 0.73 & 0.93 \\
Economic Value Index (20\%) & 0.37 & 0.49 \\
Conservation Status Index (20\%) & 0.40 & 0.43 \\
Total & 2.70 & 3.19 \\
& & \\
\hline
\end{tabular}

\section{ACKNOWLEDGEMENTS}

Special thanks to Dr. Agung Dhamar Syakti of Raja Ali Haji Maritime University, Tanjungpinang, Indonesia for rereading the manuscript. We are grateful to Dr. Heok Hui Tan from Lee Kong Chian Natural History Museum of the National University of Singapore for shared the journals.

\section{REFERENCES}

Abolhasani MH, Hosseini SA, Ghorbani R, Soudagar M, Hoseini SM. 2014. Growth, survival and stress resistance of tiger barb (Puntius tetrazona) larvae fed on linseed oil-enriched Artemia franciscana nauplii. Iranian J Fish Sci 13: 576-584.

APHA [American Public Health Association]. 2012. Standard Methods for the Examination of Water and Wastewater. 22nd ed. American Public Health Association, Virginia, USA.

Chandra G, Bhattacharjee I, Chatterjee SN, Ghosh A, 2008. Mosquito control by larvivorous fish. Indian J Med Res 127: 13-27.

Conner WH, Gosselink JG, Parrondo RT. 1981. Comparison of the vegetation of three Louisiana swamp sites with different flooding regimes. Am J Bot 68: 320-331.

Costanza R, Farber SC, Maxwell J. 1989. Valuation and management of wetland ecosystems. Ecol Econ 1: 335-361.

Dudgeon D, Arthington AH, Gessner MO, Kawabata Z, Knowler DJ, Leveque C, Naiman RJ, Prieur-Richard A, Soto D, Stiassny MLJ, Sullivan CA. 2006. Freshwater biodiversity: importance, threats, status, and conservation challenges. Biol Rev 81: 163-182.

Edwards PJ, Abviardi C. 1998. The value of biodiversity: where ecology and economy blend. Biol Conserv 83: 239-246.

Fromm O. 2000. Ecological structure and functions of biodiversity as elements of its total economic value. Environ Resour Econ 16: 303328.

Gordon ND, McMahon TA, Finlayson BL. 2004. Stream Hydrology: An Introduction for Ecologists. 2nd ed. John Wiley \& Sons Ltd., Chichester, UK.

Goudey R. 2003. Nutrient objectives for rivers and streams-ecosystem protection. EPA Victoria, Victoria

Grubb PLC. 1963. Critical factors in the genesis extent and grade of some residual bauxite and deposits. Econ Geol 58 (8): 1267-1277.

Kotellat M, Whitten AJ, Kartikasari SN, Wirjoatmodjo S. 1993. Freshwater Fishes of Western Indonesia and Sulawesi. Periplus, Hongkong.
Kottelat M, Britz R, Tan HH, Witte K. 2006. Paedocypris, a new genus of Southeast Asian cyprinid fish with a remarkable sexual dimorphism, comprises the world's smallest vertebrate. Proc R Soc B Bil Sci 273: 895-899.

Kottelat M, Lim KKP. 1994. Diagnoses of two new genera and three new species of earthworm eels from the Malay Peninsula and Borneo (Teleostei: Chaudhuriidae). Ichthyol Explor Freshw 5: 181-190.

Kottelat M, Ng PKL. 1998. Parosphromenus bintan, a new osphronemid fish from Bintan and Bangka Islands, Indonesia, with redescription of P. deissneri. Ichthyol Explor Freshw 8: 263-272.

Krebs CJ. 1999. Ecological Methodology. 2nd ed. Addison-Wesley Educational Publishers, Inc., Boston.

Lin CX, Clark MW, McConchie DM, Lancaster G, Ward N. 2002. Effects of BauxsolTM on the immobilization of soluble acid and environmentally significant metals in acid sulfate soils. Australian J Soil Res 40: 805-815.

Lundberg G, Kottelat M, Smith GR, Stiassny MLJ, Gill, AC. 2000. So many fishes, so little time: an overview of recent ichthyological discovery in continental waters. Ann Missouri Bot Gard 87: 26-62.

Menzies NW, Fulton IM, Morrell WJ. 2004. Seawater neutralization of alkaline bauxite residue and implications for revegetation. J Environ Qual 33: 1877-1884.

$\mathrm{Ng} \mathrm{HH}$, Lim KKP. 1995. A revision of the Southeast Asian catfish Genus Arakysis (Teleostei: Akysidae), with descriptions of two new species. Ichthyol Explor Freshw 6: 255-266.

Ng PKL, Kottelat M. 1994. Revision of the Betta waseri group (Teleostei: Belontiidae). Raffles Bull Zool 42: 593-611.

$\mathrm{Ng}$ PKL, Lim KKP. 1993. The Southeast Asian catfish Genus Encheloclarias (Teleostei: Clariidae), with descriptions of four new species. Ichthyol Explor Freshw 4: 21-37.

Ng PKL, Tan HH. 1997. Freshwater fishes of Southeast Asia: potential for the aquarium fish trade and conservation issues. Aquarium Sci Conserv 1: 79-90.

Parrotta JA, Knowles OH. 1999. Restoration of tropical moist forests on bauxite-mined lands in the Brazilian Amazon. Restor Ecol 7: 103116.

Parsons SE, Ware S. 1982. Edaphic factors and vegetation in Virginia coastal plain swamps. Bull Torrey Bot Club 109: 365-370.

Prentice C, Parish D. 1992. Conservation of peat swamp forest: A forgotten ecosystem. Malayan Nat J 45: 128-144.

Reinhardt RD, Hershner C. 1992. The relationship of below-ground hydrology to canopy composition in five tidal freshwater swamps. Wetlands 12: 208-216.

Riau Islands Planning Agency. 2003. Rencana Tata Ruang Wilayah Kabupaten Kepulauan Riau 2001-2010. Riau Islands Planning Agency. Batam, Riau Islands.

Roberts TR. 1981. Sundasalangidae, a new family of minute freshwater salmoniform fishes from Southeast Asia. Proc Calif Acad Sci 42: 295-302.

Sembiring S. 2008. Soil chemical and physical properties of the exbauxite mining site at Bintan Island, Riau. Jurnal Info Hutan 5: 123134. [Indonesian]

Tan HH, Tan SH, 1994. Betta miniopinna, a new species of fighting fish from Pulau Bintan, Riau Archipelago, Indonesia (Teleostei: Belontiidae). Ichthyol Explor Freshw 5: 41-44

Tan SH, Tan HH. 1994. The freshwater fishes of Pulau Bintan, Riau Archipelago, Sumatera, Indonesia. Trop Biodiv 2: 351-367.

Wargasasmita S. 2002. The freshwater fishes of endemic of Sumatra that threatened species. Jurnal Iktiologi Indonesia 2: 41-49.

Yule CM. 2010. Loss of biodiversity and ecosystem functioning in IndoMalayan peat swamp forests. Biodiv Conserv 19: 393-409. 